\title{
Estilo, enunciação e ethos discursivo em metapoema de Ferreira Gullar
}

Helba Carvalho"

\section{Resumo}

A poesia metalinguística de Ferreira Gullar constrói uma sequência de argumentos que valida não só um estilo, mas um posicionamento crítico sobre a concepção de poesia, resultando em um ethos discursivo, segundo Maingueneau (2006, 2008), de mestre, neste texto, chamado de professoral. Neste artigo, será analisado o metapoema "Muitas vozes", a fim de que se comprove, por meio de marcas estilísticas e discursivas, a maneira do poeta de ver e de pensar a poesia. No poema, observa-se uma dimensão argumentativa, conforme Amossy (2005), bem como as características do texto argumentativo, segundo Fiorin (2015). A poesia metalinguística de Ferreira Gullar direciona o olhar do coenunciador para que possa refletir e perceber a poesia de uma certa maneira; o enunciador apresenta seu ponto de vista fazendo uso dos recursos da língua, como a metáfora, a comparação, a ironia, a definição, etc.

Palavras-chave: Enunciação. Estilo. Ethos discursivo. Ferreira Gullar.

\section{Considerações iniciais}

Pensar sobre a arte moderna e contemporânea e, especialmente, sobre a poesia é refletir sobre suas formas de representação ao longo da história. O homem moderno passou a não se contentar mais apenas com a contemplação estética imediata e criou a necessidade de refletir e de pensar sobre a arte. $\mathrm{O}$ filósofo Hegel foi um dos primeiros a discutir essa tendência a partir da Idade Moderna: "o pensamento e a reflexão sobrepujaram a bela arte" (2001, p. 34). Nesse sentido, nota-se um movimento em torno de uma arte que passa a refletir sobre si mesma, a partir da segunda metade do século XIX e mais recorrentemente no século $\mathrm{XX}$, quando

\footnotetext{
Doutora em Letras pela Universidade de São Paulo. Docente do Programa de Pós-Graduação em Linguística da Universidade Cruzeiro do Sul. E-mail: augustomatraga@ yahoo.com
}

Data de submissão: mar. 2017 - Data de aceite: jan. 2018 http://dx.doi.org/10.5335/rdes.v14i1.6802 
a crítica de arte se consolida inteiramente. Trajetória semelhante ocorre com a literatura, especialmente com a poesia, que terá na figura de Charles Baudelaire (1821-1867), a expressão do poeta e do crítico de arte moderna, que, em seu célebre ensaio $O$ pintor da vida moderna (1996), sobre Constantin Guys, faz uma reflexão sobre a modernidade. O poeta da lírica moderna francesa ocupou um importante lugar na tradição dos poetas que passaram a refletir sobre a própria criação artística, bem como sobre a de artistas de sua geração.

No Brasil da primeira metade do século $\mathrm{XX}$, talvez o poeta e prosador que mais desenvolveu o papel de crítico literário e das artes tenha sido Mário de Andrade. Isso significa que, na condição de crítico literário, o poeta, ao analisar textos de outros autores, coloca em prática o metadiscurso, na medida em que comenta e avalia os procedimentos técnicos utilizados na construção de uma obra, como fez Mário, em seus ensaios e na correspondência com Manuel Bandeira e Carlos Drummond de Andrade, na qual se encontram discussões e opiniões relativas à lírica, ao modernismo e à construção poética, que vão se refletir na poesia do próprio Mário de Andrade.

Experiência semelhante a de exercer o duplo papel de poeta e crítico está na pessoa de Ferreira Gullar, na segunda metade do século XX. Sua amizade com Mário Pedrosa contribuiu para que assumisse essa dupla função, na qual o poeta constrói uma trajetória reflexiva e polê- mica que discute o estado e a função da arte na contemporaneidade. Completamente aderente ao presente, sua poesia metalinguística, diferente da de outros poetas de sua geração, como Haroldo, Augusto de Campos e Décio Pignatari, que ficaram presos a um movimento (o Concretismo) (CARVALHO, 2002), revela um fazer poético que, de forma lúcida, liberta-se de rótulos e formas estabelecidas. A poesia de Ferreira Gullar, em sua longa trajetória dos anos 1950 aos anos 2000, apresenta, como em poetas modernos e contemporâneos - Manuel Bandeira, Drummond, João Cabral de Melo Neto, os poetas marginais, Paulo Henriques Britto, só para citar alguns uma preocupação com a criação poética que se realiza por meio da forte presença de poemas metalinguísticos. No entanto, em Ferreira Gullar, a metapoesia se estabelece em um continuum e, mais do que em outros poetas, torna-se visceral, sofrendo alterações de acordo com cada momento vivido pelo poeta.

A leitura atenta da fortuna crítica (dissertações, teses, livros) sobre Gullar mostra que relacionar os seus escritos e a política é mais do que um lugar comum, tornou-se uma espécie de chamariz para, justamente, aquilo que o poeta não quer e não pensa a respeito da arte e da literatura, ou seja, o engajamento político do poeta não deve se sobrepor ao estético, conforme observa Gullar: 
Minha atitude, então, em face da poesia, era essencialmente pragmática, isto é, menos preocupada com a qualidade poética do que com o objetivo político a alcançar. Mais tarde me dei conta de que fazer má poesia não servia para nada. Ao escrever um poema, a preocupação principal tem de ser com a qualidade literária, poética. Isso me levou a elaborar melhor os poemas dessa fase e mesmo a tentar criar uma linguagem poética de qualidade a partir do vocabulário que o tema político-social inevitavelmente implica (2015, p. 58-59).

O objetivo deste artigo é analisar como a poesia metalinguística de Ferreira Gullar - representada nesta proposta pelo poema "Muitas vozes", do livro homônimo - revela um tom didático marcado por um ethos professoral que remete à imagem do mestre, no qual a voz do poeta militante de esquerda é reduzida, para dar lugar a uma voz reflexiva e, ao mesmo tempo, explicativa sobre o fazer poético, como uma forma de compreensão maior (metafísica, filosófica, ontológica) a respeito da criação, da linguagem poética e dos discursos que ela produz no ato do falar e do dizer.

\section{Estilística, enunciação e análise do discurso}

Câmara Jr. caracteriza o estilo, “em regra, por um desvio da norma linguística assente" (1961, p. 140). Já, para Possenti, a noção de "desvio" de Câmara Jr. deve ser repensada no sentido de que desviar da "norma linguisticamente assente", da gramática da língua, visto que há uma "variabilidade inerente ao próprio padrão linguístico", permite observar que "não há propriamente uma ordem canônica” (POSSENTI, 2001, p. 285).

As considerações de Possenti são esclarecedoras na medida em que propõem, no lugar do "desvio", a noção de "escolha" como constitutiva do estilo. Para pensar em estilo, deve-se admitir uma pluralidade dos códigos. Podem-se acrescentar, a essa noção de "escolha", os dois modos de arranjo que todo signo linguístico implica, como apresentou Roman Jakobson: a combinação e a seleção, cuja junção está relacionada à função poética da linguagem. A seleção

\section{[...] é feita em base de equivalência, se- melhança e dessemelhança, sinonímia e antonímia, ao passo que a combinação, a construção da sequência, se baseia na conti- guidade (JAKOBSON, 2007, p. 130).}

Na poesia, a função poética estará presente nas escolhas feitas pelo poeta, que vão revelar uma reiteração regular de unidades equivalentes, como em uma melodia na música, cujo tema se repete ou é retomado com pequenas variações.

Segundo Jean Cohen, a reiteração regular "aparece como lei constitutiva do poema [...] a redundância aumenta a força da expressividade, [...] não informa, mas exprime" (1978, p. 66). Ou, como observou Roman Jakobson:

Pode-se afirmar que na poesia a similaridade se superpõe à contigüidade e, assim, "a equivalência é promovida a princípio constitutivo da sequência". Nela toda a reiteração perceptível do mesmo conceito gramatical torna-se um procedimento poético efetivo (2004, p. 72). 
Pode-se acrescentar à ideia de Jakobson que, entre os recursos estilísticos que promovem, na poesia, a similaridade, está a metáfora, que pode ser uma das estratégias utilizadas no poema em sua dimensão argumentativa, a ser discutida mais adiante.

Amparada nos textos de Bakhtin e seu Círculo, Beth Brait, no ensaio "Estilo" (2008, p. 83), se não resolve a problemática levantada por Câmara Jr. em torno do estilo e sua individualidade "relativa", faz o leitor repensar o conceito de estilo, ao considerar a alteridade, o outro, como parte constituinte do enunciado, contrariando a visão da estilística clássica, que se ampara na subjetividade e individualidade do estilo. Brait observa que, para Bakhtin e seu Círculo,

[...] o estilo não pode separar-se da idéia de que se olha um enunciado, um gênero, um texto, um discurso, como participante, ao mesmo tempo, de uma história, de uma cultura e, também, da autenticidade de um acontecimento, de um evento (2008, p. 96).

Dessa forma, a noção de estilo considerada neste artigo se ocupa tanto do enunciado, portanto, do aspecto verbal, de suas particularidades (fônicas, morfológicas, semânticas e sintáticas), quanto da enunciação e de seus protagonistas (enunciador/coenunciador), buscando analisar o modo pelo qual o poeta se apropria da língua e a coloca em funcionamento, a fim de observar a rede de relações de sentido nos poemas analisados. Como aparato teórico, consideram-se a teoria da enunciação e a análise do discurso em diálogo com a estilística. Nesse sentido, os estudos de Émile Benveniste são fundamentais para compreender que,

[...] na enunciação, a língua se acha empregada para a expressão de uma certa relação com o mundo. A condição mesma dessa mobilização e dessa apropriação da língua é, para o locutor, a necessidade de referir pelo discurso, e, para o outro, a possibilidade de co-referir identicamente, no consenso pragmático que faz de cada locutor um co-locutor. A referência é parte integrante da enunciação (BENVENISTE, 2006, p. 84).

Nota-se que a enunciação, ao mesmo tempo em que é um ato individual de utilização da língua, converte-a em discurso, conforme observa Benveniste (2006, p. 82-83). Nesse sentido, o sujeito que "se declara locutor e assume a língua, implanta o outro diante de si”, introduzindo "aquele que fala em sua fala” (2006, p. 84). Na poesia metalinguística, observa-se como o enunciador, ao discutir o fazer poético, assume uma fala que põe em evidência o funcionamento da própria língua, apresentando o modo de enunciação, $o$ ato de comunicação verbal, muitas vezes, como tema do discurso, como se observa no fragmento do poema "Procura da poesia", de Carlos Drummond de Andrade: 


\section{[...]}

Convive com teus poemas, antes de escrevê-los.

Tem paciência, se obscuros. Calma, se te provocam.

Espera que cada um se realize e consume

com seu poder de palavra

e seu poder de silêncio.

[...] (2002, p. 118).

Observa-se, nos versos supracitados, que o enunciador, ao mesmo tempo em que instaura um eu que fala, também põe em evidência um diálogo com um $t u$ coenunciador, expresso por meio dos pronomes teus e te e pelas formas verbais coloquiais, que simulam o imperativo afirmativo: convive, tem, espera .

Segundo Benveniste:

A consciência de si mesmo só é possível se experimentada por contraste. Eu não emprego eu a não ser dirigindo-me a alguém, que será na minha alocução um $t u$. Essa condição de diálogo é que é constitutiva da pessoa, pois implica em reciprocidade - que $e u$ me torne $t u$ na alocução daquele que por sua vez se designa por eu. A linguagem só é possível porque cada locutor se apresenta como sujeito, remetendo a ele mesmo como eu no discurso. Por isso, eu propõe outra pessoa, aquela que, sendo embora exterior a "mim", torna-se o meu eco - ao qual digo tu e que me diz $t u$ (2006, p. 286, grifo do autor).

A abordagem dialógica de Benveniste, mesmo em uma perspectiva estruturalista, remete à noção de dialogismo de Bakhtin: o locutor coloca a língua em funcionamento e deixa marcas de subjetividade, de intersubjetividade, da alteridade. A identidade do sujeito se processa por meio da linguagem, na relação com a alteridade. Trata-se da "reação da palavra à palavra de outrem" como ponto de tensão entre o eu e o outro, entre forças sociais. Nesse sentido, a noção de enunciação de Bakhtin difere da de Benveniste, pois naquele se observa a dimensão discursiva, o caráter interativo, social, histórico e cultural da linguagem em perspectiva dialógica. É importante destacar que as teorias de Bakhtin não são as referências básicas para a discussão deste trabalho, mas, em alguns momentos, contribuem para as análises.

É importante comentar, nesse sentido, que a linguística da enunciação diz respeito à situação de discurso, cuja referência é a própria língua, lembrando que faz parte do objeto da linguística "o estudo dos mecanismos pelos quais o falante, apropriando-se da língua, transforma-a em discurso" (POSSENTI, 2001, p. 61), conforme Benveniste. Portanto, o que transforma a língua em discurso é a enunciação, de um eu (locutor) a um tu (alocutário).

Ao analisar o discurso metalinguístico da poesia, observa-se o plano da metaenunciação ou o: 
[...] processo pelo qual os locutores "comentam" aquilo mesmo que dizem. Tais enunciações têm a função de marcar "não coincidências", seja entre locutores (dois locutores não empregariam as mesmas palavras), seja entre discursos (já que um discurso pode ser afetado por outro), seja entre as palavras e as coisas (as palavras seriam "incapazes" de nomear de forma transparente), seja das palavras consigo mesmas (as palavras podem ter mais de um sentido) (POSSENTI, 2000, p. 99).

No poema metalinguístico, observa-se que o enunciador comenta seu próprio discurso, como um espaço em que a própria língua exibe seu funcionamento discursivo, longe de ser, portanto, mero instrumento à disposição de interlocutores. Associando essa noção ao que já foi apresentado sobre o estilo, o enunciador, ao se apropriar da língua, introduz a subjetividade, como se observa, ainda, nos versos metalinguísticos de Drummond, vistos anteriormente.

$\mathrm{O} e u$ não se projeta explicitamente, mas, ao instaurar um $t u$, faz emergir um eu que fala por meio de frases imperativas e evidencia a própria situação de enunciação, chamada por Maingueneau (2006, p. 290) de cenografia, que integra um ethos marcado por um tom professoral, didático, quase de conselho a um tu poeta. É importante ressaltar, também, que o ethos que se mostra nos versos de Drummond revela que "o enunciador deve conferir a seu destinatário, certo status para legitimar seu dizer: ele se outorga no discurso uma posição institucional e marca sua relação com um saber" (AMOSSY, 2005, p. 16), no caso, o literário, o poético. Considere-se, ainda, que esse saber ao qual se refere
Ruth Amossy, na literatura, diz respeito a uma postura de escrita associada a uma corrente da tradição literária ou, mais propriamente, a um estilo de fazer poesia que extrapola a individualidade.

A noção de ethos divulgada por Maingueneau tem como origem a Retórica de Aristóteles, ao investigar as estratégias de persuasão para tipos de indivíduos através da circulação de uma boa impressão pela forma como se constrói o discurso. Essa noção será rediscutida pelas correntes da análise do discurso e pela pragmática. Por não ser efetivamente dito no enunciado, pois é um elemento discursivo que pertence ao ato da enunciação, o ethos permanece no segundo plano; isto é, deve ser percebido, mas não como objeto do discurso. Da mesma forma como a cenografia pode reforçar ou comprometer o discurso de um determinado enunciado, assim também é o ethos; no entanto, aquela diz respeito a uma cronografia e a uma topografia, ao passo que este diz respeito a uma certa imagem que o enunciador constrói de si mesmo durante a enunciação, enquanto corteja o seu público na busca por sua adesão.
Além da persuasão por argumentos, a noção de ethos permite, de fato, refletir sobre o processo mais geral da adesão de sujeitos a uma certa posição discursiva. O processo é particularmente evidente quando se trata de discursos como o da publicidade, da filo- sofia, da política, etc., que - diferentemente dos que têm a ver com gêneros "funcionais", como os formulários administrativos ou os manuais - não têm por objetivo uma adesão imediata, mas devem conquistar um público que tem o direito de ignorá-los ou de recusá- -los (MAINGUENEAU, 2008, p. 69-70). 
É importante ressaltar que a subjetividade manifesta no discurso é concebida como uma voz que não pode ser dissociada do corpo que enuncia. Segundo Maingueneau:

A problemática do ethos pede que não se reduza a interpretação dos enunciados a uma simples decodificação; alguma coisa da ordem da experiência sensível se põe na comunicação verbal. As ideias suscitam a adesão por meio de uma maneira de dizer que é também uma maneira de ser. Apanhado num ethos envolvente e invisível, o co-enunciador faz mais que decifrar conteúdos: ele participa do mundo configurado pela enunciação, ele acede a uma identidade de algum modo encarnada, permitindo ele próprio que um fiador encarne (2008, p. 29).

Partindo do pressuposto de que todo discurso tem uma dimensão argumentativa, José Luiz Fiorin (2015), ao contrário dos estudos de Ducrot e Anscombre, que se fazem na esteira da argumentação na língua, propõe estudar discursivamente a argumentação. Além dos operadores argumentativos e dos marcadores de pressuposição apontados por Ingedore Koch, o autor elenca os principais tipos de argumentos, como comparação, metáfora, paradoxo, ironia, definição, exemplificação, dilema e pergunta.

Para a análise do poema "Muitas vozes", a teoria utilizada é pautada na estilística-discursiva, mais especificamente, na relação entre os recursos linguísticos utilizados (sonoros, lexicais, sintáticos, semânticos) e os efeitos de sentido produzidos no plano da enunciação e do discurso. Para os estudos estilísticos (a noção de estilo) e enunciativos, foram consideradas as teorias de Câmara Jr. (1961, 1977), Mikhail Bakhtin (2003), Sírio Possenti (2000, 2001), Nilce Sant’Anna Martins (1989) e Émile Benveniste (2006). Para a análise do discurso de linha francesa, são discutidos os conceitos de Dominique Maingueneau (2006, 2008), especialmente sobre ethos discursivo e cenografia. Finalmente, para as considerações sobre metalinguagem/ metadiscurso e argumentação presentes nos poemas metalinguísticos, são citados os estudos de Roman Jakobson (2004, 2007), Sírio Possenti (2000, 2001), Ruth Amossy (2005), José Luiz Fiorin (2015) e Ingedore Koch (2007).

\section{O ethos discursivo no poema "Muitas vozes", de Ferreira Gullar}

"Muitas vozes" é título de poema e livro de Ferreira Gullar, de 1999. Sendo assim, já figura em si a sinédoque e a metonímia: ao mesmo tempo em que é parte de um todo, um poema metalinguístico que define o estilo "individual" do fazer poético de um enunciador, revela e representa as outras muitas vozes (poemas do livro e também dos leitores), como o todo de uma parte (poema do livro). Nesse sentido, o poema explicita a rede de relações discursivas que nele operam e o faz por meio de um ethos expositivo que também assume um ethos professoral: 
Meu poema

é um tumulto:

a fala

que nele fala

outras vozes

arrasta em alarido.

(estamos todos nós

cheios de vozes

que o mais das vezes

mal cabem em nossa voz:

se dizes pêra,

acende-se um clarão

um rastilho

de tardes e açúcares

ou

se azul disseres,

pode ser que se agite

o Egeu

em tuas glândulas)

A água que ouviste

num soneto de Rilke

os ínfimos

rumores no capim

o sabor

do hortelã

(essa alegria)

a boca fria

da moça

o maruim

na poça

a hemorragia

da manhã

tudo isso em ti

se deposita

e cala.

Até que de repente

um susto

ou uma ventania

(que o poema dispara)

esses fósseis à fala.

chama

Meu poema

é um tumulto, um alarido:

basta apurar o ouvido.

(GULLAR, 2000, p. 453).
O poema "Muitas vozes" é composto por seis estrofes, cada uma formada por um número irregular de versos irregulares, configurando uma estrutura visualmente assimétrica, que é uma das marcas da poesia de Gullar. Na primeira e na última estrofes do poema, observa-se uma simetria promovida pelo paralelismo sintático. Também ressalta a retomada lexical na construção dos versos compostos por: nome, verbo de ligação e nome. Formados por verbo de ligação ("ser") e predicativo do sujeito, na ordem direta, os dois primeiros versos da primeira e da última estrofes sugerem a ideia de circularidade promovida não só pela repetição, mas também pela necessidade de o enunciador retomar a reflexão acerca do fazer poético. Nas duas estrofes mencionadas, as palavras "tumulto" e "alarido" apresentam uma aproximação semântica, na medida em que representam, metaforicamente, o barulho das muitas vozes presentes no poema, um efeito paradoxal, se confrontado à estaticidade do verbo "ser", como se observa:

\author{
Meu poema \\ é um tumulto: [...] \\ Meu poema \\ é um tumulto, um alarido: [...]
}

Os versos anteriores compõem frases de predicado nominal que exprimem uma definição (MARTINS, 1989, p. 133) do poema na perspectiva do enunciador, bem como seu modo pessoal de 
interpretar o fazer poético. Esse tipo de construção sintática reforça a presença da subjetividade na enunciação. Nilce Sant'Anna Martins também observa que o verbo ser "indica o aspecto da duração indeterminada" (1989, p. 133), sugerindo que o enunciador possui uma definição já estabelecida de um modo de fazer poesia. A definição, como um argumento quase lógico, segundo Fiorin (2015, p. 118), impõe "um determinado sentido" e se orienta para "convencer o coenunciador de que um dado significado é aquele que deve ser levado em conta". Por isso, para $o$ autor, ela pode ser conflitante.

$O$ verbo ser, assim como boa parte dos verbos do poema-fala, arrasta, estamos, cabem, dizes, chama, basta, etc. -, está no presente do indicativo, acentuando a duração indeterminada, bem como o presente da própria enunciação, como observou Benveniste:

Da enunciação procede a instauração da categoria do presente, e da categoria do presente nasce a categoria do tempo. [...] O presente formal não faz senão explicitar o presente inerente à enunciação, que se renova a cada produção de discurso, e a partir deste presente contínuo, coextensivo à nossa própria presença, imprime na consciência o sentimento de uma continuidade que denominamos "tempo" (2006, p. 85-86).

O pronome possessivo "meu”, repetido na primeira e na última estrofe, explicita o eu da enunciação, momento em que o enunciador se apresenta como sujeito e possuidor do poema ou, como destacou Benveniste:
A "subjetividade" de que tratamos aqui é a capacidade do locutor para se propor como sujeito. [...] Ora, essa subjetividade, quer a apresentemos em fenomenologia ou em psicologia, como quisermos, não é mais que a emergência no ser de uma propriedade fundamental da linguagem. É "ego" que diz ego. Encontramos aí o fundamento da "subjetividade" que se determina pelo status lingüístico da "pessoa". [...] (2006, p. 286).

Ainda sobre os versos das estrofes citadas, destaca-se o uso repetido, na mesma estrutura, dos dois pontos, dispostos no segundo verso das duas estrofes, abrindo e fechando a fala do enunciador, que se move em reflexões acerca da natureza dialógica do seu poema: "a fala/ que nele fala/outras vozes/arrasta em alarido". Mais do que explicar a natureza de seu poema, o enunciador personifica o poema e atribui a ele uma voz própria, no jogo com o verbo de elocução "falar": "a fala/que nele fala".

A segunda estrofe se abre num grande parêntese, que só se fecha no último verso da terceira estrofe. A noção de subjetividade no discurso é marcada pela presença do pronome na primeira pessoa do singular, "meu", que cede lugar para os pronomes na primeira pessoa do plural "nós", "nossa", incluindo o coenunciador e o diálogo do poeta com seus poemas anteriores e com a tradição moderna. $\mathrm{O}$ uso do pronome "nós" acaba por unir enunciador e coenunciador, eu e tu, acentuando a sugestão de pluralidade em uma única voz, que incorpora diferentes vozes, maneiras de dizer, de saber o mundo. Dessa forma, os pronomes pessoais, representados pelo plural nós, "são o primeiro ponto de 
apoio para a revelação da subjetividade na linguagem" (BENVENISTE, 2006, p. 288), o que, na esfera discursiva, remete a uma intenção de dialogar, de debater e pensar sobre a existência dessas vozes dentro de todos nós, colocando o poeta e seu coenunciador em pé de igualdade. Depreende-se daí o ethos argumentativo, que levanta as suas hipóteses em um tom lúdico e com fortes elementos de sinestesia, que, ao mesmo tempo, revelam, intertextualmente, um ethos mítico da cena validada da criação no texto bíblico de Gênesis, ao elencar os elementos que surgem no poema na mesma sequência daquele capítulo da Bíblia, como se pode observar, a seguir, nos versos a partir da terceira estrofe:

se dizes pera,

acende-se um clarão

E disse Deus: Haja luz; e houve luz.

(Gênesis 1:3).

um rastilho

de tardes e açúcares

E Deus chamou à luz Dia; e às trevas chamou Noite. E foi a tarde e a manhã, o dia primeiro.

(Gênesis 1:5).

ou

se azul disseres,

pode ser que se agite

o Egeu

em tuas glândulas)

E disse Deus: Haja uma expansão no meio das águas, e haja separação entre águas e águas.
E fez Deus a expansão, e fez separação entre as águas que estavam debaixo da expansão e as águas que estavam sobre a expansão; e assim foi.

E chamou Deus à expansão Céus, e foi a tarde e a manhã, o dia segundo.

E disse Deus: Ajuntem-se as águas debaixo dos céus num lugar; e apareça a porção seca; e assim foi.

E chamou Deus à porção seca Terra; e ao ajuntamento das águas chamou Mares; e viu Deus que era bom.

(Gênesis 1:6-10).

E, na quarta estrofe:

A água que ouviste num soneto de Rilke os ínfimos

rumores no capim

o sabor

da hortelã

(essa alegria)

E disse Deus: Produza a terra erva verde, erva que dê semente, árvore frutífera que dê fruto segundo a sua espécie, cuja semente está nela sobre a terra; e assim foi.

(Gênesis 1:1).

Nota-se que o diálogo entre a criação do mundo e a criação do poema produz uma das vozes desse tumulto, que se junta a outras vozes justapostas, como as da memória de outros poemas de Ferreira Gullar e também no diálogo com o poeta checo Rainer Maria Rilke, ainda na quarta estrofe, ao fazer referência à água da fonte no soneto "Fonte Romana", traduzido por Augusto de Campos: 
Fonte Romana

$$
\text { Borghese }
$$

Duas velhas bacias sobrepondo suas bordas de mármore redondo. Do alto a água fluindo, devagar, sobre a água, mais em baixo, a esperar,

muda, ao murmúrio, em diálogo secreto, como que só no côncavo da mão, entremostrando um singular objeto: o céu, atrás da verde escuridão;

ela mesma a escorrer na bela pia, em círculos e círculos, constantemente, impassível e sem nostalgia,

descendo pelo musgo circundante ao espelho da última bacia que faz sorrir, fechando a travessia.

(RILKE, 1994, p. 45).

E a "boca fria da moça", que introduz a quinta estrofe, pode ser a voz de outro poema de Rilke, sobre a amada morta:

\section{O mundo estava no rosto da amada}

O mundo estava no rosto da amada e logo converteu-se em nada, em mundo fora do alcance, mundo-além.

Por que não o bebi quando o encontrei no rosto amado, um mundo à mão, ali, aroma em minha boca, eu só seu rei?

Ah, eu bebi. Com que sede eu bebi. Mas eu também estava pleno de mundo e, bebendo, eu mesmo transbordei.

[...] (RILKE, 1994, p. 56).
Percebe-se que essa profusão de vozes - apenas para citar algumas, pois o poema certamente retoma outras vozes que nos exigiriam "apurar o ouvido" faz alusão, também, à Torre de Babel do Gênesis 11, na forma como o enunciador se refere à multiplicidade de vozes no poema como "tumulto", algo que tanto exprime barulho quanto desordem e confusão, próprios da cena da Babel bíblica. Esse sentido é observado na primeira e na última estrofes, em que a voz do enunciador apresenta a chave para que se possa compreender a sua poesia, trazendo o ethos professoral.

O "alarido" de vozes no poema pode ser percebido no nível fônico, a partir da aliteração da alveolar /s/, destacada na segunda e na terceira estrofes:

(eStamoS todoS nóS

cheioS de vozeS

que o mais daS vezeS

mal cabem em noSSa voZ:

Se dizeS pêra,

aCende-Se um clarão

um raStilho

de tardeS e aÇúcareS

ou

Se azul diSSeres,

Pode Ser que Se agite

o Egeu

em tuaS glândulaS)

Além da aliteração em /s/, nota-se uma convergência fônica, que se dá na rima externa entre as palavras "nós" e "voz", e um jogo sonoro de "vozes" e "vezes", da segunda estrofe. $\mathrm{Na}$ terceira estrofe, os 
verbos na segunda pessoa do singular ("dizes" e "disseres") retomam o diálogo do enunciador com o outro (tu), iniciado na estrofe anterior pelo uso do verbo na primeira pessoa do plural ("estamos"). Os versos da segunda estrofe, mais uma vez, seguem depois dos dois pontos e se destacam pela forma como o enunciador exemplifica as "muitas vozes", formulando alguns casos particulares da presença delas no poema, que, segundo Fiorin (2015, p. 185), podem "comprovar uma tese" pelo exemplo, como: as palavras "pêra" e "azul" aparecem em itálico, destacando-se que esses significantes podem gerar inúmeros significados, pois cada palavra, ao ser acionada (dita), recupera imagens na memória de quem enuncia e permite uma série de associações, como a do "azul" com o mar "Egeu". Percebe-se, também, um jogo de elementos sinestésicos, na medida em que são acionados o paladar e o olfato ("pera", "açúcares", "glândulas"), a visão, a audição e o paladar ("clarão", "rastilho", "tardes", "azul”, "Egeu" (o sal do mar).

É importante destacar que as palavras "pera" e "azul" retomam vozes anteriores do próprio poeta, visto que Ferreira Gullar escreveu um poema intitulado "As peras", publicado no livro A luta corporal. A palavra "azul" é frequente em seus poemas. Parece haver ainda um jogo de palavras entre "dizes pera" e "desespera", assim como entre "se azul disseres" com "se as o disseres", isto é, se disseres as "tardes e os açúcares”, da estrofe anterior, como se o poeta estivesse sugerindo, no primeiro caso, que se alguém se desespe- ra, acende-se um clarão - portanto, acende-se um clarão do meio da escuridão, o que entra em acordo com o fiat lux bíblico. No segundo caso, o poeta põe em contato uma série de imagens - a luz, a tarde, o açúcar, a pera, o azul (do céu, onde se acende o clarão, ou do mar Egeu) - que sugerem o revirar do sabor e da doçura da pera na boca, ativando assim as glândulas salivares, justaposto ao revirar das ondas nas tardes ensolaradas da Grécia, já que o poeta não escolhe qualquer mar, mas o Egeu, cenário da Ilíada e da Odisseia de Homero, reforçando aquele ethos mítico já tratado.

Como já se observou na quarta estrofe, os versos iniciais, "A água que ouviste/ num soneto de Rilke”, e a expressão “a boca fria/da moça", na quinta estrofe, podem fazer referência aos sonetos "Fonte Romana" e "O mundo estava no rosto da amada", ambos de Rainer Maria Rilke, e mostram um dos ecos (dos outros) da poesia moderna no poema de Ferreira Gullar. Isso coloca em evidência uma das vozes do $t u$ (Rilke), que recai sob a voz do eu e a incorpora em seu discurso, justificando a necessidade de o discurso literário se relacionar a outras maneiras de dizer do literário, como notou Bakhtin:

[...] as formas de enunciação literária, de uma obra literária, só podem ser apreendidas na unicidade da vida literária, em conexão permanente com outras espécies de formas literárias. Se encerrarmos a obra literária na unicidade da língua como sistema, se a estudarmos como um monumento lingüístico, destruiremos o acesso a suas formas como formas da literatura como um todo (BAKHTIN, 2003, p. 105). 
As referências a outras vozes não param em Rilke. O enunciador elenca uma série de imagens prosaicas e do mundo da natureza, que são expressas numa sequência de sintagmas nominais, formados a partir do final da quarta estrofe, dando continuidade na quinta estrofe: "os ínfimos rumores no capim/o sabor/da hortelã [...]// a boca fria/da moça/o maruim/na poça/a hemorragia/ da manhã". Essas imagens ilustram a ideia bakhtiniana de que "a enunciação é de natureza social" (2004, p. 109); o enunciador só constrói o seu poema a partir das inúmeras relações que estabelece com o mundo, com o contexto no qual se insere. A aproximação entre as imagens prosaicas e as da natureza é reforçada, também, pelo uso da rima toante da vogal "i", da rima consoante "hortelã" e "manhã" e "moça" e "poça", como se observa:

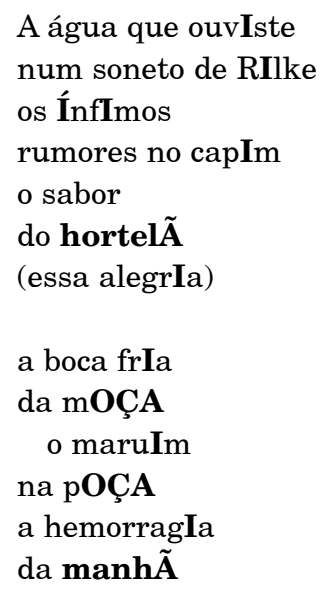

A estrofe é marcada pela continuação de um quadro sinestésico, no qual se misturam audição, visão (“água”, "rumores", "maruim"), paladar, olfato e tato ("capim”, "sabor", "hortelã”, "boca fria”), compondo uma aproximação semântica de algumas palavras que compõem o universo da natureza. A expressão entre parênteses "essa alegria" divide a estrofe simetricamente em duas partes de quatro versos cada uma, função semelhante à da palavra "ou" no meio da terceira estrofe.

Como forma de resumir as imagens anteriores, a sexta estrofe se inicia pelo pronome indefinido "tudo", sugerindo a síntese das "muitas vozes" que o enunciador tem depositadas dentro de si, como "fósseis" que, metaforicamente, representam os restos preservados de discursos de outros sujeitos, gradativamente resgatados na fala do enunciador. Sendo assim:

tudo isso em ti

se deposita

e cala.

Até que de repente

um susto

ou uma ventania

(que o poema dispara)

chama

esses fósseis à fala.

A última estrofe fecha o poema com a retomada dos dois primeiros versos da primeira estrofe, reafirmando a definição de poema e do fazer poético. A expressão final "apurar o ouvido" valoriza não somente o sentido da audição, mas a capacidade que o poeta deve ter, no seu fazer poético, de ouvir o(s) outro(s), de 
ser coenunciador e incorporar outros discursos, reafirmando a ideia central do poema, que, ao reiterar as palavras voz e vozes, coloca em evidência as pessoas do discurso na enunciação literária:

Meu poema

é um tumulto, um alarido:

basta apurar o ouvido.

Pode-se dizer, ainda, que os recursos de expressão da subjetividade, representados no poema pelo uso do pronome possessivo na primeira pessoa do singular ("meu"), na primeira e na última estrofes, e pelos pronomes na primeira pessoa do plural ("nós", "nossa"), na segunda estrofe, bem como a referência à segunda pessoa, por meio do uso dos sujeitos desinenciais, em "dizes", "disseres", "ouviste", e do pronome "ti", na terceira, na quarta e na quinta estrofes, permitem observar que o discurso do enunciador se estabelece a partir de um diálogo com o outro. Esse diálogo instaura um ethos que se constrói a partir de um "processo interativo de influência sobre o outro" (MAINGUENEAU, 2008, p. 17), na medida em que o enunciador argumenta, ao usar exemplos, como um estilo se constrói sobre outros ("A água que ouviste/num soneto de Rilke). A partir de si mesmo, o poeta, no seu exercício metalinguístico, recupera, em novos poemas, algumas imagens e o estilo de seus poemas anteriores.

\section{Considerações finais}

O poema metalinguístico de Ferreira Gullar não apenas expõe como também instaura, dialogicamente, o seu processo criativo e, ainda, o do outro: "estamos todos nós/cheios de vozes/que o mais das vezes/mal cabem em nossa voz". O estilo "individual" só se projeta a partir do social, revelando, ainda, que o poema metalinguístico manifesta um ethos cuja noção se depara com a "adesão dos sujeitos a um certo discurso" (MAINGUENEAU, 2008, p. 17) e, como se trata de um poema que fala da própria forma de constituição desse gênero e de sua linguagem em particular, também, ilustra a definição do que seja o próprio discurso.

A análise buscou destacar os recursos linguísticos (traços expressivos comuns) e os discursos presentes, que compuseram diferentes ethé, com o objetivo de mostrar a presença mais recorrente de um ethos didático, professoral, prescritivo, que apresenta um discurso reflexivo e filosófico sobre quem é o poeta e sobre o processo do fazer poético.

Em "Muitas vozes", a experiência do enunciador revela um fazer poético que emerge de uma pluralidade de vozes, que, mesmo fossilizadas, podem ser acionadas a qualquer momento, tornando o diálogo poético possível, mesmo que tumultuoso. As imagens da natureza, claras e frescas, permitem um jogo sinestésico e de aproximações sonoras, semânticas, posicionais e sintáticas. Dos cinco sentidos, pode-se dizer que a 
audição é a mais explorada, visto que o eu lírico ressalta a importância de se reconhecer que a voz do poeta não é única em seu poema, nele ecoam vozes de outros tempos e sujeitos, como a do poeta Rilke. Assim, o ethos discursivo que se configura no poema recai sobre o outro, fazendo com que o destinatário procure aderir a um tipo de comportamento poético que reconhece, no ato de criação do poema, o diálogo com estilos, poetas, enfim, com enunciados anteriores.

\section{Style, enunciation and discoursive ethos in a metapoem of Ferreira Gullar}

\begin{abstract}
The metalinguistic poetry of Ferreira Gullar constructs a sequence of arguments which validates not only a style, but critical positioning about the conception of poetry, resulting in a discoursive ethos, according to Maingueneau (2006, 2008) of a master, hereinafter called professoral. This article focuses on the metapoem "Muitas vozes", in order to prove, by means of stylistic and discoursive marks, the way this poet sees and thinks his poetry. In the forementioned poem, an argumentative dimension can be observed, according to Amossy's observations (2005), as well as the carachteristics of the argumentative text, according to Fiorin (2015). The metalinguistic poetry of Ferreira Gullar guides the view of the coenunciator so he/she can reflect and experience poetry in a certain manner; the enunciator presents his point of view making use of language resources,
\end{abstract}

such as metaphor, comparison, irony, definition, etc.

Keywords: Enunciation. Style. Discoursive ethos. Ferreira Gullar.

\section{Referências}

AMOSSY, R. (Org.). Imagens de si no discurso: a construção do ethos. São Paulo: Contexto, 2005.

ANDRADE, C. D. Poesia completa. Rio de Janeiro: Nova Aguilar, 2002.

BAKHTIN, M. M. Estética da criação verbal. Tradução de Paulo Bezerra. São Paulo: Martins Fontes, 2003.

BAUDELAIRE, C. O pintor da vida moderna. In:__. Sobre a modernidade. São Paulo: Paz e Terra, 1996.

BENVENISTE, E. Problemas de lingüística geral II. 2. ed. Tradução de Eduardo Guimarães et al.; revisão técnica de tradução Eduardo Guimarães. Campinas: Pontes, 2006.

BÍBLIA SAGRADA. Versão de João F. Almeida. Disponível em: <http://biblia.com. br/joao-ferreira-almeida-corrigida-revisada-fiel/>. Acesso em: 20 jun. 2016.

BRAIT, B. (Org.). Bakhtin: conceitos-chave. São Paulo: Contexto, 2008.

CÂMARAJR., J. M. Contribuição à estilística da língua portuguesa. Rio de Janeiro: Ao Livro Técnico, 1977.

Dispersos. Rio de Janeiro: Fundação Getúlio Vargas, 1961.

CARVALHO, H. Da poesia concreta ao poema-processo: um passeio pelo fio da navalha. 2002. Dissertação (Mestrado em Literatura Brasileira) - Faculdade de Filosofia, Letras e Ciências Humanas, Universidade de São Paulo, São Paulo, 2002. Disponível em: <http:// www.teses.usp.br/teses/disponiveis/8/8149/tde04072002-103858/>. Acesso em: 15 set. 2016. 
COHEN, J. Estrutura da linguagem poética. São Paulo: Cultrix, 1978.

FIORIN, J. L. Argumentação. São Paulo: Contexto, 2015.

GULLAR, F. Toda poesia. Rio de Janeiro: José Olympio, 2000.

Autobiografia poética e outros textos. Belo Horizonte: Autêntica, 2015.

HEGEL, F. Curso de Estética I. São Paulo: Edusp, 2001.

JAKOBSON, R. Linguística e comunicação. São Paulo: Pensamento-Cultrix, 2007.

Linguística, poética, cinema. São Paulo: Perspectiva, 2004.

KOCH, I. Desvendando os segredos do texto. São Paulo: Cortez, 2003.

Argumentação e linguagem. São

Paulo: Cortez, 2004.

MAINGUENEAU, D. Ethos, cenografia, incorporação. In: AMOSSY, R. (Org.). Imagens de si no discurso: a construção do ethos. Tradução de D.F.C. São Paulo: Contexto, 2008. p. 11-29.

. Discurso literário. São Paulo: Contexto, 2006.

MARTINS, N. S. Introdução à estilística: a expressividade na língua portuguesa. 2. ed. São Paulo: Edusp, 1989.

POSSENTI, S. Discurso, estilo e subjetividade. São Paulo: Martins Fontes, 2001.

. Metaenunciação: uma questão de interdiscurso e de relevância. Revista Estudos da Linguagem, Belo Horizonte, v. 9, n. 1, p. 91-108, jan./jun. 2000.

RILKE, R. M. Rilke: poesia - coisa. Tradução de Augusto de Campos. Rio de Janeiro: Imago, 1994. 